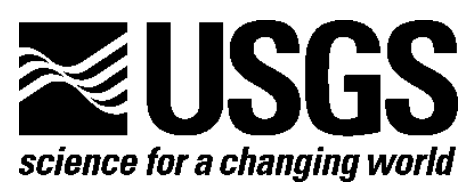

In cooperation with the Alaska Division of Geological and Geophysical Surveys and the University of Alaska-Fairbanks

\title{
Paleoseismology of the Denali Fault System at the Schist Creek Site, Central Alaska
}

By Stephen F. Personius, Anthony J. Crone, Patricia A.C. Burns, and Ned Rozell

Open-File Report 2015-1225

U.S. Department of the Interior

U.S. Geological Survey 


\section{U.S. Department of the Interior SALLY JEWELL, Secretary}

\section{U.S. Geological Survey \\ Suzette M. Kimball, Director}

U.S. Geological Survey, Reston, Virginia: 2015

For more information on the USGS—-the Federal source for science about the Earth, its natural and living resources, natural hazards, and the environment-visit http://www.usgs.gov or call 1-888-ASK-USGS

For an overview of USGS information products, including maps, imagery, and publications, visit http://www.usgs.gov/pubprod

To order this and other USGS information products, visit http://store.usgs.gov

Suggested citation:

Personius, S.F., Crone, A.J., Burns, P.A.C, and Rozell, Ned, 2015, Paleoseismology of the Denali fault system at the Schist Creek site, central Alaska: U.S. Geological Survey Open-File Report 2015-1225, 15 p., 1 oversize plate, http://dx.doi.org/10.3133/ofr20151225.

ISSN 2331-1258 (online)

Any use of trade, firm, or product names is for descriptive purposes only and does not imply endorsement by the U.S. Government.

Although this information product, for the most part, is in the public domain, it also may contain copyrighted materials as noted in the text. Permission to reproduce copyrighted items must be secured from the copyright owner. 


\section{Contents}

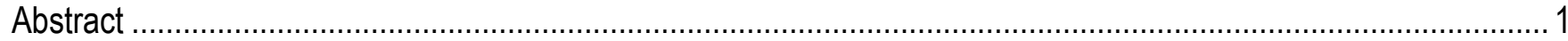

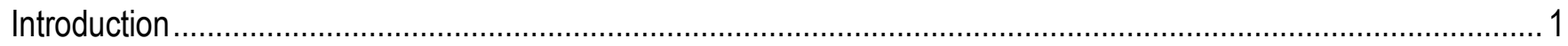

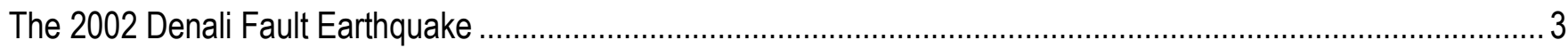

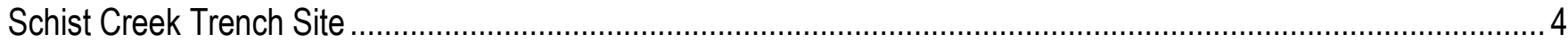

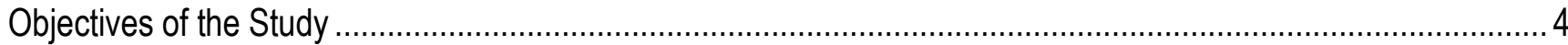

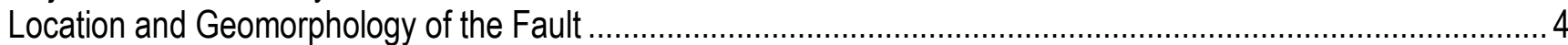

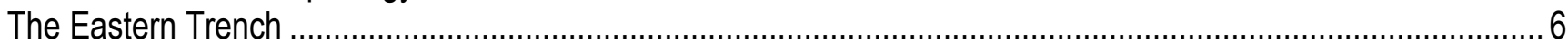

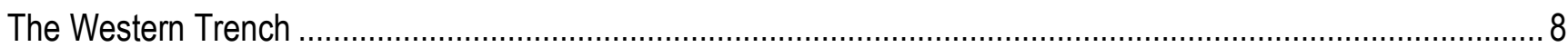

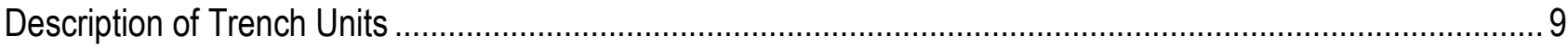

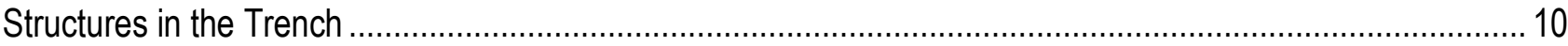

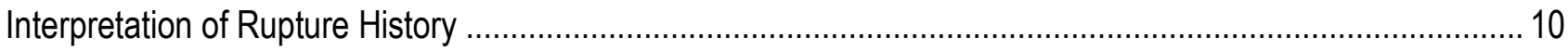

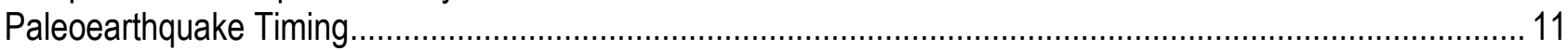

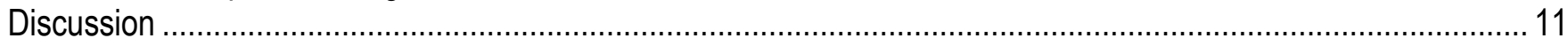

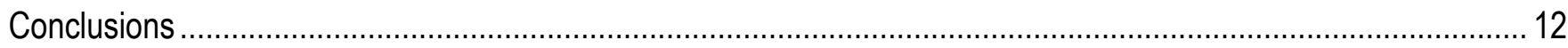

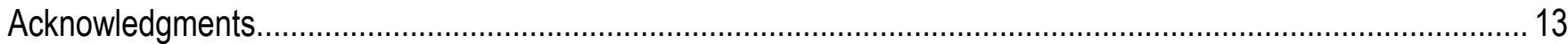

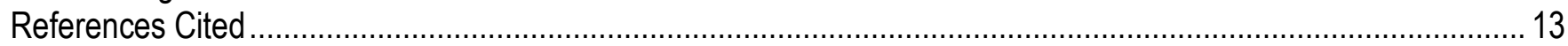

\section{Figures}

Figure 1. Plate-tectonic setting $(A)$ and regional map $(B)$ of Denali fault system, central Alaska...................... 2

Figure 2. Oblique view of lidar-derived digital elevation model of the eastern Denali fault system...................... 3

Figure 3. Surficial geologic map $(A)$ and detailed site map $(B)$ of the Schist Creek area................................ 6

Figure 4. View to the east showing the prominent topographic expression of the Denali fault.......................... 7

Figure 5. Photograph $(A)$ and Sketch $\log (B)$ of the Eastern trench at the Schist Creek site............................. 8

Figure 6. View to the northwest showing the scarp and Western trench at the Schist Creek site....................... 9

Figure 7. Logs and photomosaics of the Western trench at the Schist Creek site........................................ 15

\section{Tables}

Table 1. Data for radiocarbon samples from the Western trench, Schist Creek site...................................... 10

Table 2. Inferred late Holocene paleoseismic history of the Schist Creek site............................................... 12 


\title{
Paleoseismology of the Denali Fault System at the Schist Creek Site, Central Alaska
}

\author{
By Stephen F. Personius ${ }^{1}$, Anthony J. Crone ${ }^{1}$, Patricia A.C. Burns², and Ned Rozell ${ }^{3}$
}

\begin{abstract}
Two hand-dug trenches at the Schist Creek site on the Denali fault system in central Alaska exposed evidence of four surface-rupturing earthquakes on the basis of upward terminations of fault strands and at least one buried, scarp-derived colluvial wedge. Limited radiocarbon ages provide some constraints on times of the ruptures. The youngest rupture (PE1) likely occurred about 200-400 years ago, the penultimate rupture (PE2) is younger than 1,200 years old, the third event back (PE3) occurred between 1,200 and 2,700 years ago, and the oldest rupture (PE4) occurred more than 2,700 and less than 17,000 years ago. Evidence for a possible additional rupture (PE4?) is equivocal, and probably is related to earthquake PE4. On the basis of a nearby measured slip rate of $9.4 \pm 1.6$ millimeters per year and the long interevent times between our documented ruptures, we believe that our paleoseismic record at this site is incomplete. We suspect one undocumented earthquake between PE1 and PE2 and one or perhaps two more earthquakes between PE2 and PE3. We found stratigraphic evidence in the trenches for only four or possibly five (PE4?) earthquakes, but the addition of two or three inferred earthquakes yields a record of eight possible surface ruptures at the Schist Creek site. Our interpretation of the paleoseismic history at the site is consistent with recurrence intervals of several hundred years on this section of the Denali fault system.
\end{abstract}

\section{Introduction}

Quaternary faulting and widespread seismicity throughout much of Alaska are driven by oblique subduction of the Pacific plate and adjacent Yakutat subplate beneath the North American plate at a rate of about 5.5 centimeters per year $(\mathrm{cm} / \mathrm{yr})($ fig. $1 \mathrm{~A})$. Subduction-related deformation extends northward into Alaska for a distance of more than 900 kilometers $(\mathrm{km})$ (Haeussler, 2008; Koehler and others, 2012). Dextral slip on the Denali fault system, a major intracontinental fault system (fig. $1 B$ ), accommodates an appreciable amount of this deformation in the interior of the state (Haeussler, 2008; Bemis and others, 2015).

The Denali fault system arcs across interior Alaska through the Alaska Range and Denali National Park from the north shore of Bristol Bay near Togiak (Koehler and others, 2012), to near Haines on the Alaska Panhandle. The system extends southward offshore into the Chatham Strait (St. Amand, 1957; Plafker and others, 1994) or becomes part of a more diffuse onshore shear zone and eventually connects with the Queen Charlotte-Fairweather fault system (Elliot and others, 2010). The fault system accommodates a large fraction of the tectonic deformation in mainland Alaska (Matmon and others, 2006; Bemis and others, 2015) and has had at least $38 \mathrm{~km}$ of lateral slip since the late Eocene (Reed and Lanphere, 1974). More than 2,600 km of the Denali fault system shows evidence of Quaternary faulting (U.S. Geological Survey and Alaska Department of Natural Resources, 2006; Koehler, 2013). Measurements of the late Pleistocene dextral slip rate along the fault system range from $\sim 5$ to 13 millimeters per year (mm/yr) (Plafker and others, 1994; Matmon and others, 2006; Mériaux and others, 2009; Haeussler and others, 2012).

Our study at the Schist Creek site (fig. $1 B$ ) is part of a larger group effort to document the chronology of recent earthquakes along a substantial fraction of the Denali fault system (Schwartz and others, 2005, 2014; Seitz and others, 2008). The Schist Creek site is one of 17 sites where the group has collected data on Holocene paleoearthquakes on the fault system (Schwartz and others, 2014.)

\footnotetext{
${ }^{1}$ U.S. Geological Survey, Geologic Hazards Science Center, Box 25046 MS 966, Denver, CO 80225

${ }^{2}$ Alaska Division of Geological and Geophysical Surveys, now with Alaska Department of Natural Resources, Fairbanks, AK 99709-4699

${ }^{3}$ Geophysical Institute, 903 Koyukuk Drive, University of Alaska-Fairbanks, Fairbanks, AK 99775-7320
} 


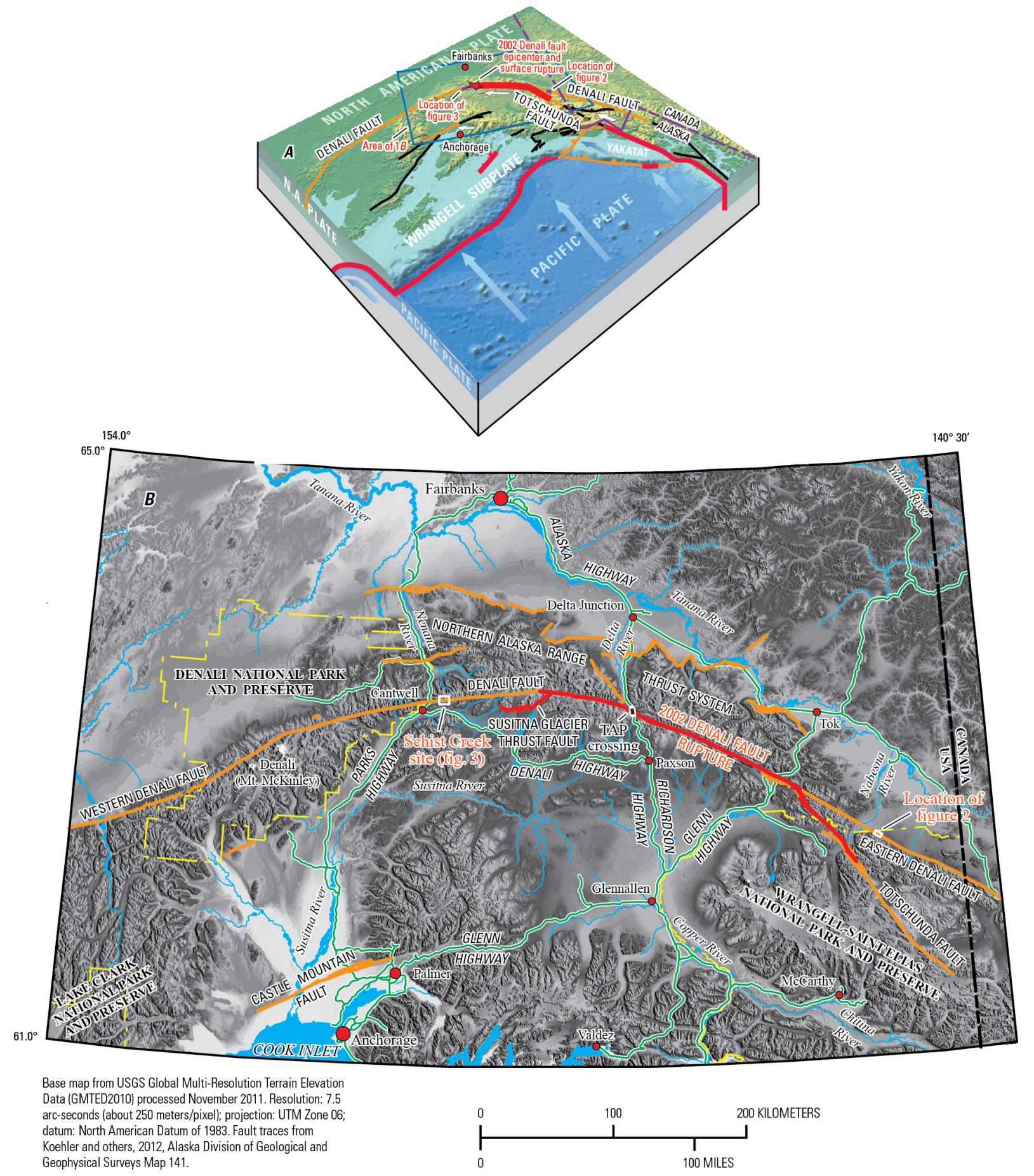

Figure 1. A, Schematic diagram of plate-tectonic setting and Denali fault system in Alaska and adjacent part of Canada. Subduction of the Pacific plate beneath the North American and smaller subplates (the Yakatat and Wrangell) is causing counterclockwise rotation in southern Alaska, which is driving the right-lateral movement on the Denali fault system. Fault colors denote age of most recent rupture: red-historic; orange-Holocene; black-pre-Holocene. Note location of Schist Creek site about 53 kilometers west of the epicenter of the 2002 earthquake. Image from NASA Earth Observatory web site: (http://earthobservatory.nasa.gov/Features/denali). B, Regional map of Denali fault system in south-central Alaska and westernmost Canada; faults that ruptured in 2002 shown in red; other Holocene faults shown in orange. Note locations of figures 2 and 3, and the location of the Trans-Alaska Pipeline (TAP)/Denali fault crossing. 


\section{The 2002 Denali Fault Earthquake}

The 3 November 2002, moment magnitude (M)7.9 earthquake in central Alaska, which was the largest strike-slip earthquake in North America in about 150 years, produced surface rupture on parts of three separate but interconnected faults (Eberhart-Phillips and others, 2003). The rupture initiated on the previously unknown 48-km-long Susitna Glacier thrust fault (fig. 1B) (Crone and others, 2004), progressed eastward onto the Denali fault system for $226 \mathrm{~km}$, and finally diverted onto the Totschunda fault where it continued for another $66 \mathrm{~km}$ (Haeussler and others, 2004). The earthquake generated $341 \mathrm{~km}$ of surface rupture, produced a maximum right-lateral displacement of 8.8 meters $(\mathrm{m})$, and had average dextral offsets of 4.5 to $5.1 \mathrm{~m}$. It also induced numerous spectacular, massive landslides in the epicentral area (Jibson and others, 2004).

The 2002 earthquake generated the first documented historical rupture on the fault system, although part of the fault system may have ruptured during a large-magnitude earthquake in 1912 (Carver and others, 2004). However, the fault system has an obvious topographic expression across most of the state (Riehle and others, 1997), and in detail is characterized by distinct, sharply expressed fault-related geomorphic features (fig. 2) (EarthScope Alaska Denali Totschunda LiDAR Project, 2008). The fault system's tectonic geomorphology at both local and regional scales makes it clear that large prehistoric earthquakes repeatedly ruptured much of the fault system in Holocene and late Pleistocene time.

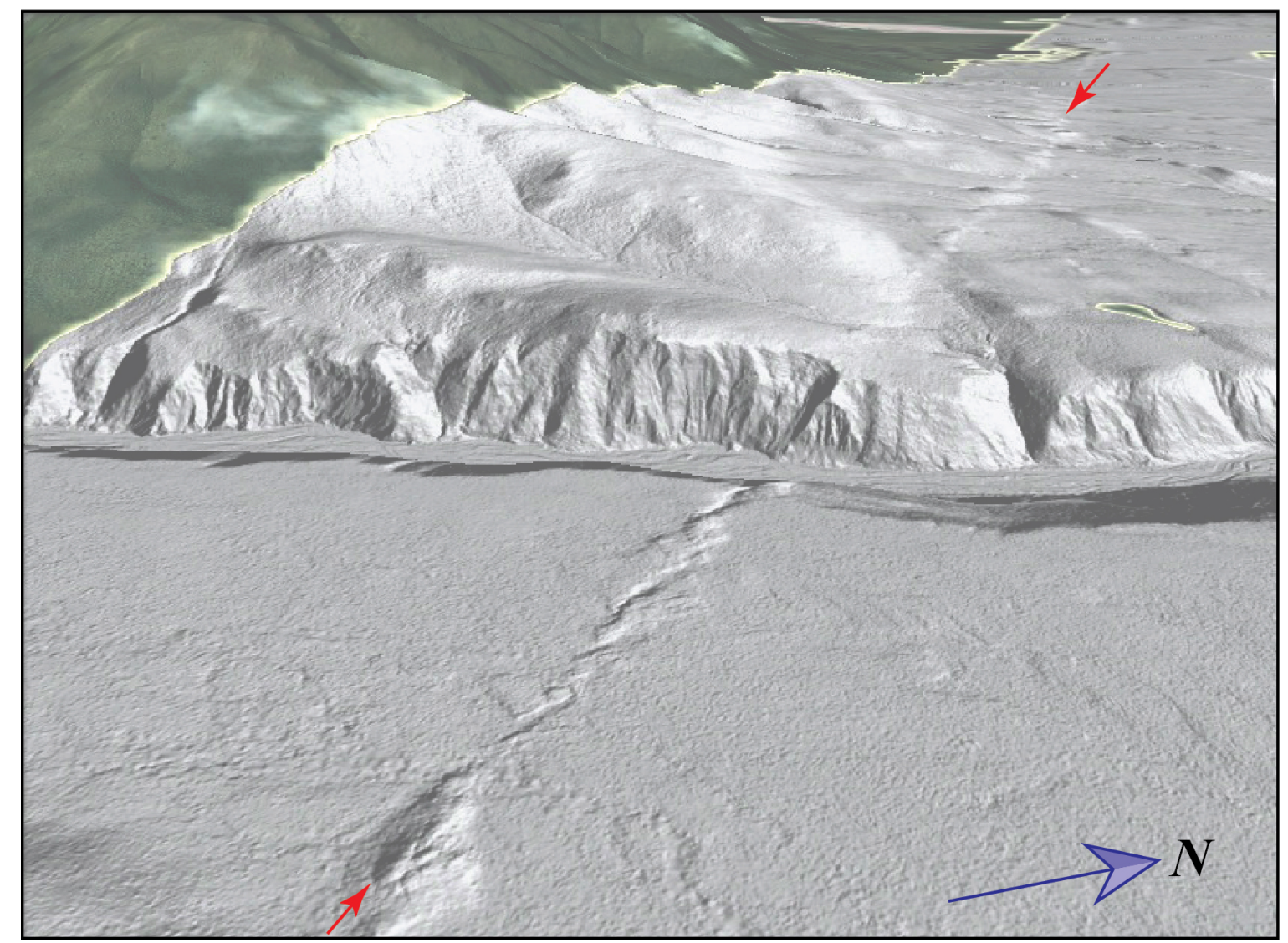

Figure 2. Oblique view (to west-northwest) of lidar-derived digital elevation model of the eastern Denali fault system draped on Google Earth image showing detailed geomorphic expression indicative of youthful movement on the fault. Trace of the fault [marked by red arrows] is well expressed in the low-relief fluvial terrace in the foreground. This site is located about $15 \mathrm{~km}$ east-southeast of the Nabesna River; fig. $1 B$ ) fault trace crosses the unnamed creek in this view at $62.482048^{\circ} \mathrm{N}$., $142.192149^{\circ} \mathrm{W}$. (see fig. $1 B$ ). Lidar data are from the EarthScope Alaska Denali-Totschunda LiDAR dataset, which covers the eastern third of the Denali and the northern part of the Totschunda faults, and are available from the OpenTopography Facility (http://www.opentopography.org).

The 2002 surface rupture crossed the route of the 1.2-m-diameter (48-inch) Trans-Alaska Pipeline (TAP) and produced about $5.3-5.5 \mathrm{~m}$ of right-lateral slip and about $0.6-0.8 \mathrm{~m}$ of vertical displacement at the pipeline crossing (fig. $1 B$; Fuis and Wald, 2003; Haeussler and others, 2004, Honegger and others, 2004). When the pipeline was constructed in the 
1970s, it was specifically designed to accommodate about $6 \mathrm{~m}$ of right-lateral ground displacement, about $(\sim) 1.5 \mathrm{~m}$ of vertical displacement, and high levels of strong motion from an earthquake on the Denali fault system (Hall and others, 2003). Because of these design parameters, no oil was spilled, the pipeline performed as expected during the earthquake, and it was returned to service within days.

\section{Schist Creek Trench Site}

\section{Objectives of the Study}

The Denali fault system has been long recognized as having the potential to generate very large earthquakes in interior Alaska. Even so, prior to the 2002 Denali fault earthquake there was little support for paleoseismic studies of the fault because the region has a small population and little critical infrastructure (the Trans-Alaska Pipeline being a principal exception). Following 2002, renewed interest in acquiring data to refine site-specific hazard assessments allowed us to conduct field studies along both the newly ruptured and other unruptured parts of the fault system. In mid-August 2005, we hand-excavated two trenches at a location we designated the Schist Creek site to obtain information about the history of recent ruptures along the west-central section of the fault system. In this report, we summarize the data collected, present photomosaic logs of one trench, and discuss preliminary results of the timing of past surface ruptures at the site.

\section{Location and Geomorphology of the Fault}

The Schist Creek site is located along the southern margin of the Alaska Range about $11 \mathrm{~km}$ east of the Parks Highway and $17.5 \mathrm{~km}$ east-northeast of Cantwell, Alaska (fig. 1B). The site is in the upper part of the Schist Creek drainage system where several south-flowing tributaries of Schist Creek merge and turn westward (fig. $3 A$ ). The site is $\sim 53 \mathrm{~km}$ west of the epicenter and $\sim 44 \mathrm{~km}$ west of the westernmost surface rupture on the Susitna Glacier fault associated with the 2002 Denali fault earthquake (Haeussler, 2009).

We reconnoitered by helicopter the section of the Denali fault system between the Parks Highway near Denali National Park and a paleoseismic study site about $26 \mathrm{~km}$ to the east in the Wells Creek drainage. On the basis of three factors, Schist Creek appeared to be a location where data defining the times of recent surface ruptures might be recovered. First, the tectonic geomorphology indicates that recent fault movements appear to be localized on a single, simple strand as compared with other sites where multiple strands are present (fig. $3 B$ ). Second, surficial deposits at the site seemed likely to contain enough datable organic material for us to utilize high-precision, accelerator mass spectrometry radiocarbon dating to constrain the timing of surface ruptures. Third, because the main drainage that extends across the fault and into the range was incised tens of meters below the sites we intended to trench, little or no fluvial erosion of the stratigraphic record of the most recent paleoearthquakes was expected.

Because the remote location of the Schist Creek site required helicopter access and limited our field time to four days, we focused on excavating trenches, interpreting and logging the exposures, and collecting samples for radiocarbon dating, and thus we had little opportunity to evaluate the geomorphology of the surrounding area on the ground or to make a detailed site map. However, our limited aerial and ground reconnaissance and examination of high-resolution ( $0.5 \mathrm{~m} / \mathrm{pixel})$ imagery and preexisting geologic maps show that the trace of the Denali fault is developed in a dynamic landscape primarily of latest Quaternary glacial moraines associated with small tributary glaciers flowing southward from the Alaska Range, and glacial outwash from a larger, westward-flowing glacier emanating from the Bruskasna Creek drainage to the east (fig. $3 \mathrm{~A}$ ). Matmon and others (2006) dated similar deposits about $3 \mathrm{~km}$ to the west at $17.0 \pm 1.8$ kiloannum (ka), which indicate the faulted deposits likely date to the last glacial maximum in the region. The easternmost branch of Schist Creek is incised 20$30 \mathrm{~m}$ into the moraine complex, and a large landslide overlies a similar moraine complex in the drainage directly west of our site.

We hand-dug two trenches across youthful-appearing fault scarps near the eastern branch of Schist Creek: a 7.5-mlong trench on the eastern side of the drainage (N. 63.46499 $;$ W. $\left.148.58604^{\circ}\right)$ and a $5.5-\mathrm{m}-$ long trench on the western side of the drainage (N. 63.46487; W. 148.59047) (figs. 3B, 4). 


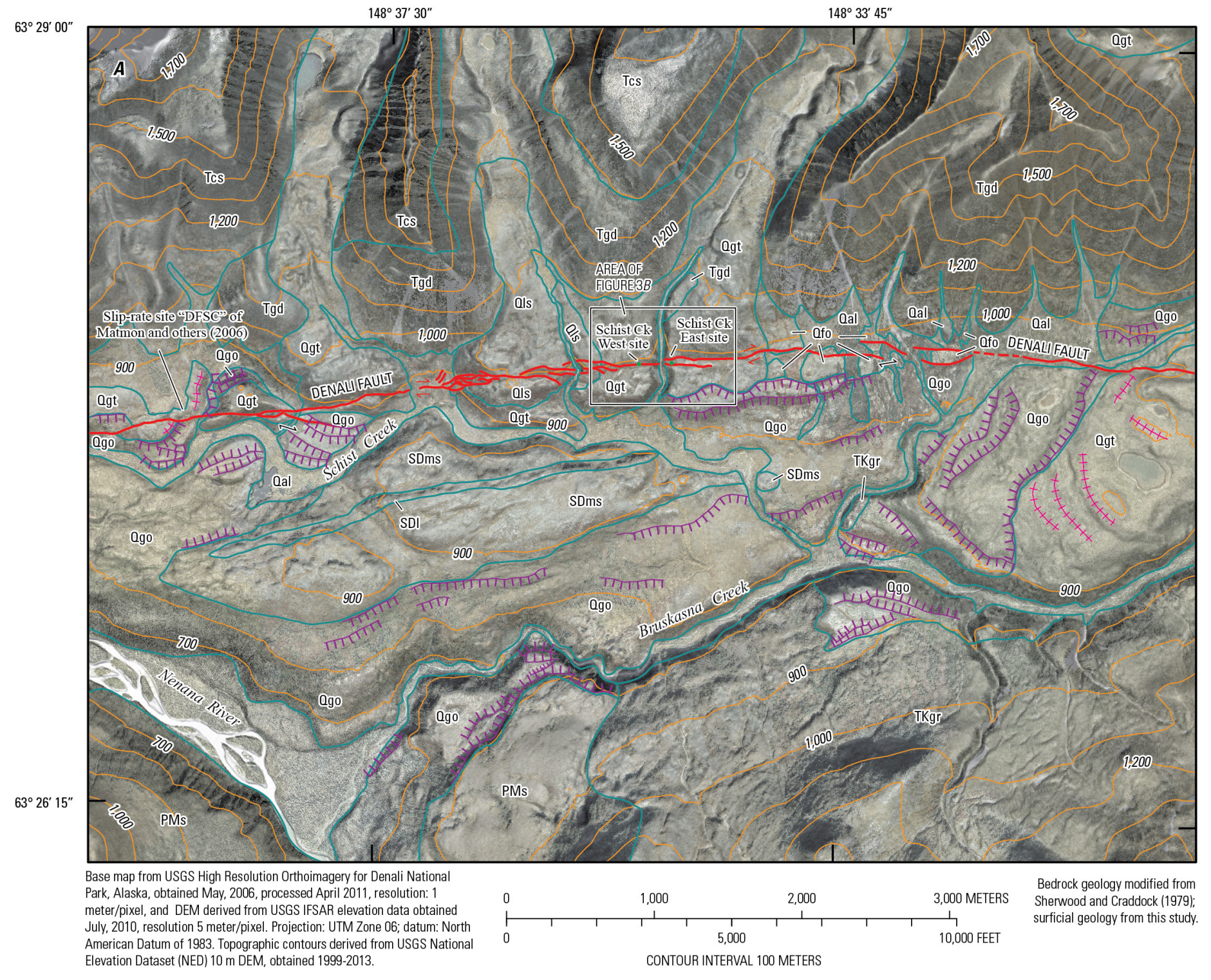

Figure 3. A, Surficial geologic map of the Denali fault system in vicinity of the Schist Creek trench site, modified from Sherwood and Campbell (1979). Matmon and others (2006) measured an average slip rate of $9.4 \pm 1.3 \mathrm{~mm} / \mathrm{yr}$ at their site "DFSC," which is located about $3 \mathrm{~km}$ west of our site. See figure $3 B$ for Explanation of symbols and units. 


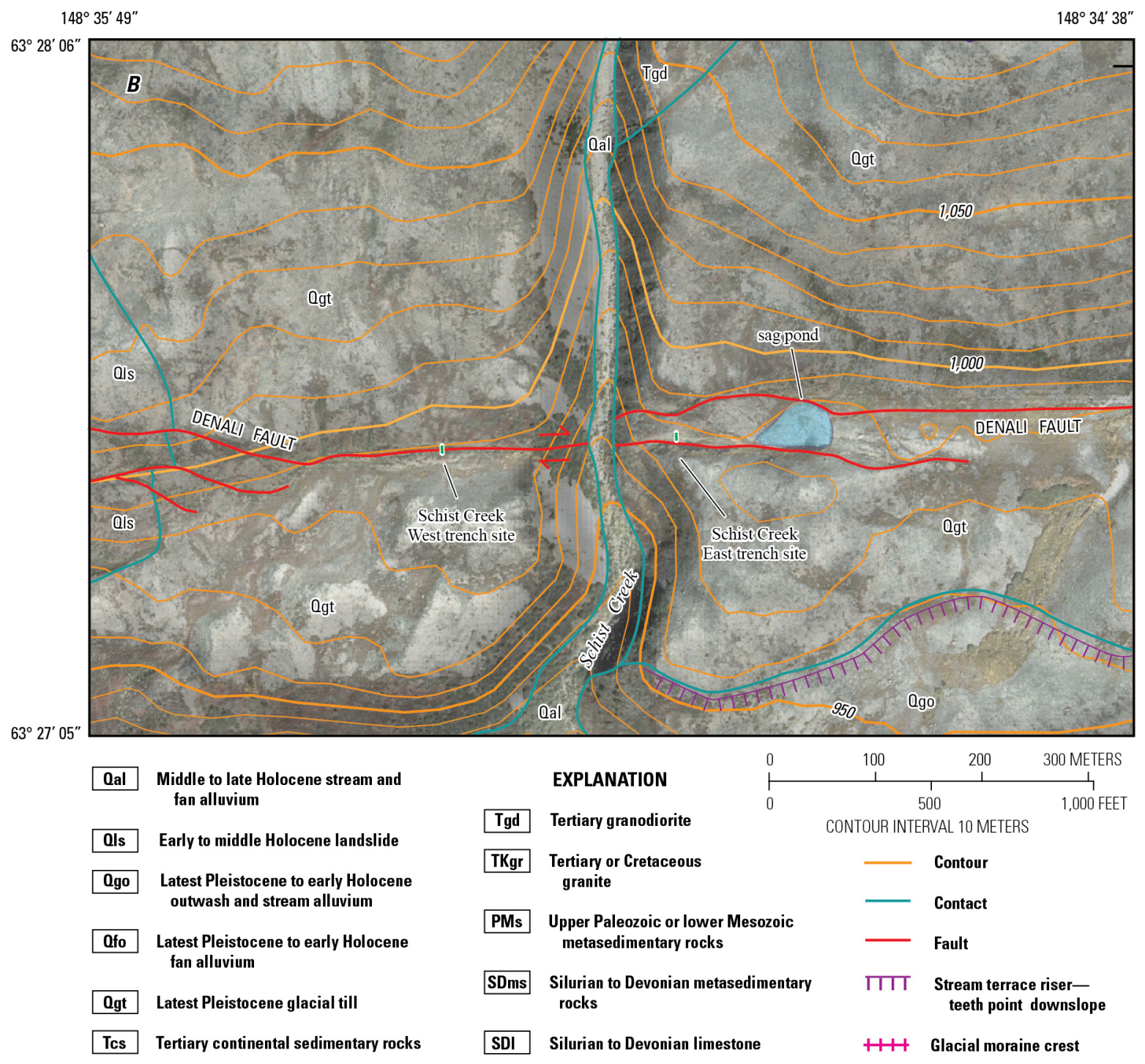

Figure 3B. Detailed surficial geologic map of the Schist Creek site.

\section{The Eastern Trench}

The Eastern trench was located in a narrow, fault-controlled, east-west-trending gully (figs. 4, 5A). The upper (eastern) end of the gully extends to within a few tens of meters of an ephemeral pond that we interpret as a sag pond. After evaluating the morphology of the gully on the ground, we excavated the southern margin because it is the steeper of the two sides, and it has a sharp upper crest. We interpreted the steep slope and sharp crest to be more indicative of youthful ground rupture in the gully. The trench began in the relatively flat gully bottom and extended southward about $2 \mathrm{~m}$ up the steep 


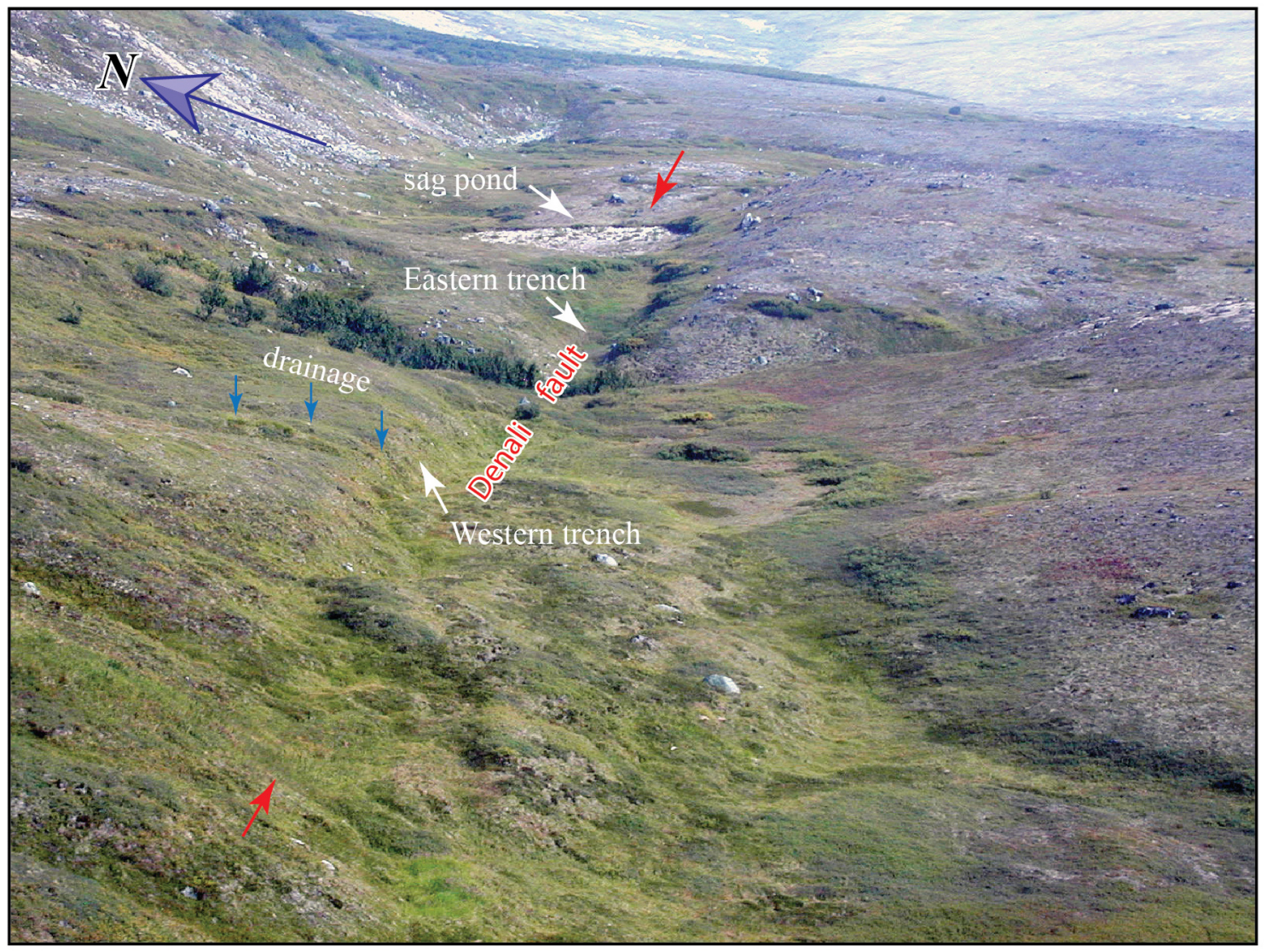

Figure 4. View to the east showing the prominent topographic expression of the Denali fault (red arrows) at Schist Creek site, and the locations of the Eastern and Western trenches and the prominent sag pond $\sim 100 \mathrm{~m}$ east of the Eastern trench.

southern side. The trench was about $1.2-1.5 \mathrm{~m}$ deep in the flat bottom and increased to $1.7 \mathrm{~m}$ deep up the steep side. We encountered numerous large (greater than $(>) 0.5$-m-wide) boulders throughout the trench, including a boulder more than $1 \mathrm{~m}$ in diameter at the northern end of the trench that precluded further excavation.

In our brief evaluation of the eastern trench, we recognized four discrete stratigraphic units. In the trench bottom, a well-oxidized, brown, sandy pebble, cobble, and boulder gravel was exposed that we interpret as outwash or ground moraine. The gravel is overlain by a yellowish-brown sandy silt that contained distinct, highly contorted, 0.5 - to 2 -cm-thick beds of tan silt, which we interpret as either ephemeral pond deposits or oxidized beds of volcanic ash. Where the trench crossed the central part of the gully, the yellowish-brown sandy silt is overlain by a light brown, massive silt we interpret as a sag(?) pond deposit. Toward the margins of the gully, the light brown, massive silt is interstratified with silty, sandy, pebble, cobble, and boulder gravel that we interpret as colluvium derived from the gully slopes.

With the exception of the contorted bedding in the lower sandy silt deposit, the Eastern trench failed to expose evidence of fault-related deformation. We suspect that recent ruptures on the fault were either localized on the north side of the gully upslope from our excavation, or they were buried beneath young sediments below the base of our trench. Given the difficulty of digging in the bouldery deposits and our time constraints, we terminated work in this trench and concentrated on the Western trench. Because of the absence of faulting, we did not map this trench in detail, so herein we present only a sketch $\log$ of the generalized trench stratigraphy (fig. $5 B$ ). 

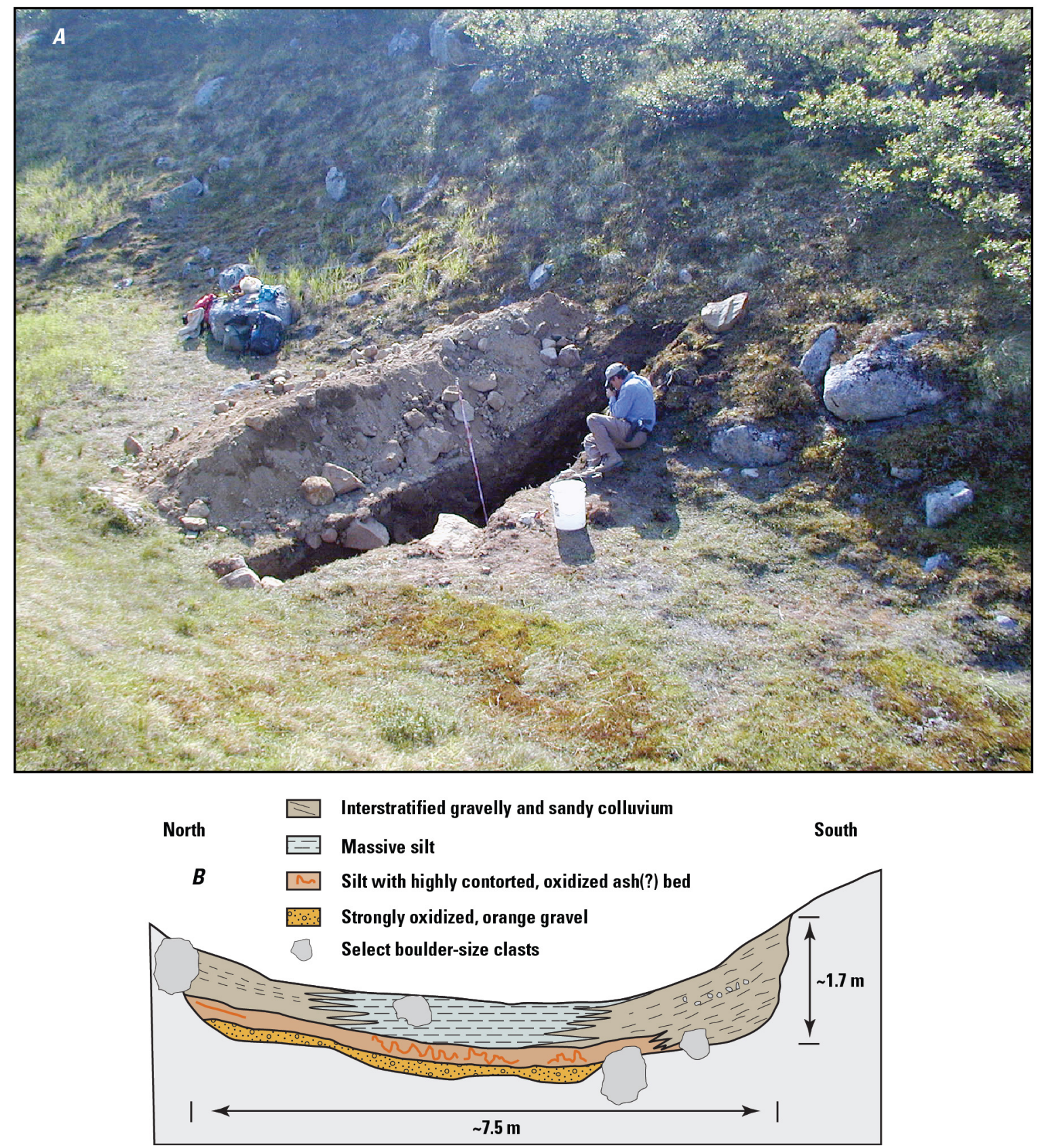

Figure 5. $\quad A$, View (looking southeast), and B, Sketch map of the Eastern trench at the Schist Creek site; all features and dimensions are schematic and not to scale.

\section{The Western Trench}

We hand-dug a 5.5-m-long trench on the western side (Western trench) of Schist Creek where the fault trace is marked by a steep, 3-m-high, south-facing scarp (fig. 6). This trench exposed a sequence of gravelly and bouldery colluvia overlain by silt and fluvial deposits on the lower part of the scarp. Because it also exposed multiple fault strands throughout the exposure, we spent the rest of our field time mapping both walls of the trench and collecting samples for radiocarbon analysis. 


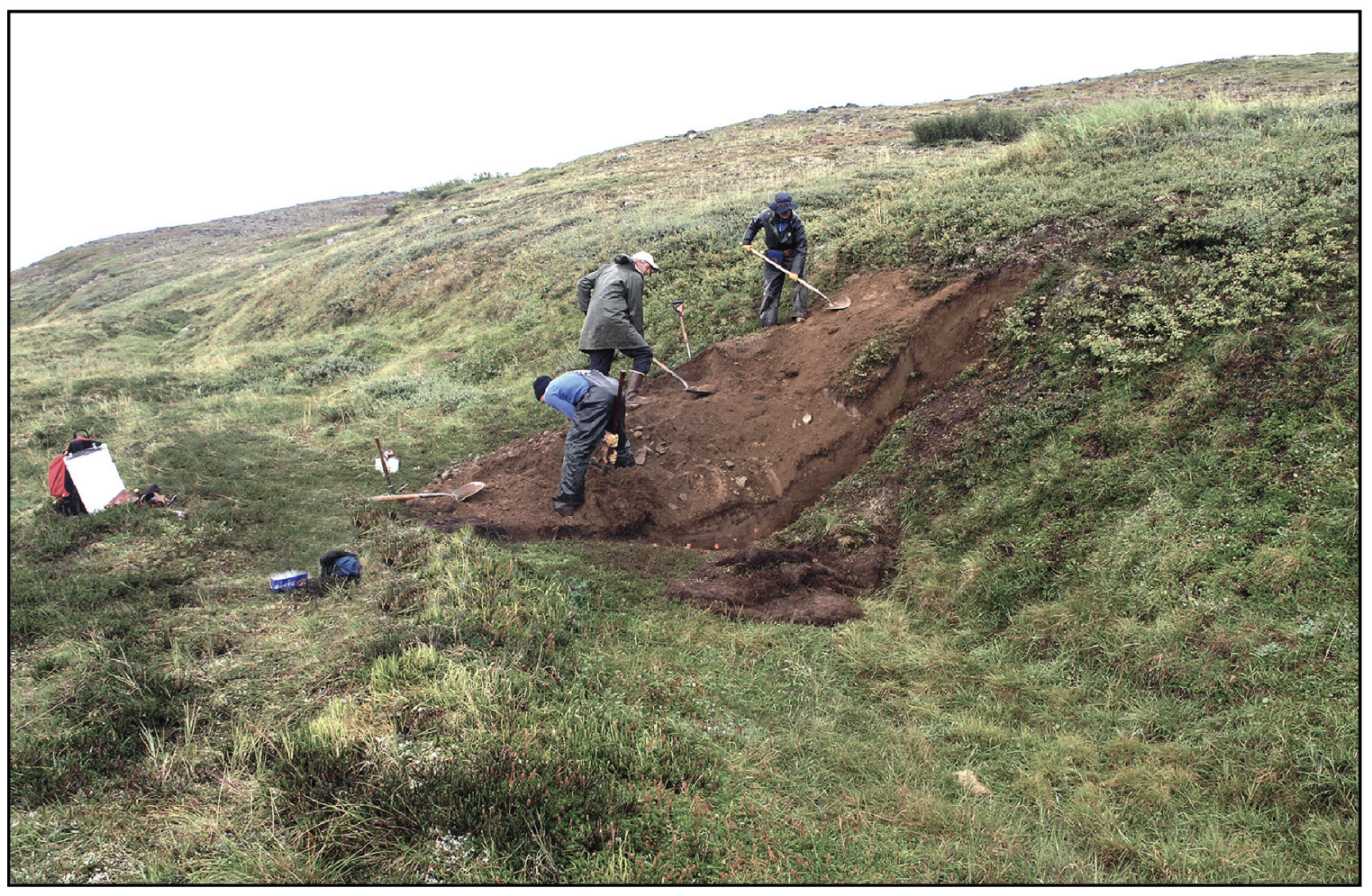

Figure 6. View to the northwest showing the scarp and Western trench at the Schist Creek site.

\section{Description of Trench Units}

We divided the stratigraphy in the Western trench into eight discrete units and locally included a ninth unit of trench spoil on the log of the east wall (fig. 7). In the northern, uplifted wall of the fault zone were exposed small pockets of unit 1 (oldest), which is composed of relatively well sorted, coarse pebble and cobble gravel that we interpret as glacial outwash. Unit 2, the basal unit along most of the trench's length, consists of two subunits: unit $2 \mathrm{a}$ is a poorly sorted sandy, pebble to boulder gravel; unit $2 b$ is an even more poorly sorted mixture of pebbles, cobbles, and boulders in a sandy silt matrix. Unit 2a is present only in the northern half of the trench, north of faults FE6 and FW6. We interpret both subunits of unit 2 as different facies of the glacial diamicton that mantles the landscape surrounding the trench site. Unit 3 is a poorly sorted mixture of pebbles and cobbles in a coarse sandy to silty matrix; unit 3? is a similar deposit that coarsens upslope and occupies the same stratigraphic position in the northern part of the trench. We interpret the latter two units as likely correlative deposits of fault-scarp colluvium probably related to the same paleoearthquake. Unit 4 is a distinctive, massive, orangish silt that we interpret as a loess deposit that has likely been remobilized by cryogenic processes such as solifluction and frost heaving. The loess is restricted to the steep northern slope of the scarp and is truncated southward by faults FW5 and FE5.

Unit 5 represents a distinct change in sedimentation; it is a fluvial deposit present on the south side of faults FW5 and FE4 at the base of the scarp. It consists of a bedded and interstratified sequence of cut-and-fill channel gravels and graybrown sand and silt. The unit was deposited by streamflow along the base of the scarp, where channels were incised into the underlying diamicton and later filled with well-bedded fluvial silt, sand, and occasional lenses of pebble gravel. Erosion of the surface of unit $2 \mathrm{~b}$ is primarily restricted to the prominent channels south of trench meter 2.0 in the east wall and $1.8 \mathrm{~m}$ in the west wall. Unit 6 is a brown sand that we interpret to be the finer grained facies of the channel-fill deposits at the base of the scarp. In the east wall, the sand extends several meters northward to the middle of the scarp. The presence of unit 6 sand on such a steep slope suggests to us that the northern part of the unit may be eolian sand blown up the growing scarp. The top of unit 6 is marked by a 1-cm-thick root mat, which we interpret as the top of a preexisting ground surface. Unit 7 is a distinctive, yellowish-gray, medium- to fine-grained sand that mantles most of the scarp, and thus it is likely an eolian deposit. Unit 8 is the modern tundra surface composed of dark gray, medium- to fine-grained sand that is bound together with a thick, coherent mat of roots. Unit 9 shown on the east wall in figure 7 is a zone of disturbance and spoil that resulted from excavating the trench. 


\section{Structures in the Trench}

The Western trench exposed a 6-m-wide fault zone that consists of numerous fault strands that terminate at several stratigraphic levels (fig. 7). The known primary sense of slip on the Denali fault system is right lateral, but the orientation of the overlying scarp and stratigraphic relations in the trench also indicate a down-to-the-south vertical component. Major displacement is primarily restricted to faults FE5 in the east wall and FW5 and FW6 in the west wall, which are located at the midpoint of the scarp, but the other traces are equally useful for deciphering the history of surface ruptures at the site.

\section{Interpretation of Rupture History}

Working backward in time, evidence for the most-recent earthquake is manifest in several fault strands that extend very close to the modern ground surface. These strands include FE4 (northern strand), FE5, FW5, FW8, and FW9, which all terminate at the lower contact of unit 7. These strands extend so close to the ground surface that we infer that the youngest surface rupture (paleoearthquake 1 or PE1) occurred only a few hundred years ago because only units 7 and 8 have formed on the scarp since PE1. A very young age is supported by a radiocarbon sample from unit 7 in the east wall that yielded a modern (post-1950) age (table 1).

Table 1. Data for radiocarbon samples from the Western trench, Schist Creek site.

[Samples analyzed at the Center for Accelerator Mass Spectrometry (CAMS), Lawrence Livermore National Laboratory in August 2006 by Gordon G. Seitz]

\begin{tabular}{|c|c|c|c|c|}
\hline Sample name & CAMS ID & ${ }^{14} \mathrm{C}$ age (yr) & $\begin{array}{c}\text { Calibrated age }^{1} \\
\text { (cal yr } \pm 2 \sigma)\end{array}$ & Comment \\
\hline SCW-R01 & 126276 & Modern & - & $\begin{array}{l}\text { East wall; minimum age for PE1. } \\
\text { Collected carbonized fibers from a } \\
\text { 95- to } 105-\mathrm{mm} \text { thick zone in the } \\
\text { channel sample to avoid modern } \\
\text { fibers. }\end{array}$ \\
\hline SCW-R02 & 126277 & $1,265 \pm 35$ & $1,210 \pm 100$ & $\begin{array}{l}\text { East wall; maximum age for PE2. } \\
\text { Sampled bulk, sediment-rich peaty } \\
\text { layer. }\end{array}$ \\
\hline SCW-R03 & 126278 & $2,600 \pm 35$ & $2,730 \pm 100$ & $\begin{array}{l}\text { West wall; maximum age for PE3. } \\
\text { Sampled fine-layered peat stringer } \\
\text { containing carbonized fibers, } \\
\text { moderately organic-rich, bulk } \\
\text { sample. }\end{array}$ \\
\hline
\end{tabular}

${ }^{1}$ Ages calibrated to calendrical yr (before 1950) with OxCal v4.2.3 Bronk Ramsey (2009) and the IntCal13 atmospheric curve (Reimer and others, 2013).

Evidence of the penultimate earthquake (PE2) is present in both walls of the trench: faults FE1, FE2, FE4 (southern strand), FE6, and FW1 all terminate at the unit 6/unit 5 boundary, indicating that the top of unit 5 was the ground surface at the time of PE2. This interpretation is further supported by a slight enrichment in organic material in the uppermost part of unit 5. A radiocarbon sample from the top of this organic horizon yielded a calendar-corrected age of 1,210 $\pm 100 \mathrm{cal}$ yr $\mathrm{BP}$ (table 1), which we interpret as a maximum-limiting age for PE2.

Upward terminations of faults FW1 (southern splay), FW2, FW3, FW4, and FE3 at the unit 2/unit 5 boundary are evidence of a third earthquake (PE3) that occurred sometime between deposition of units 2 and 4 and the deposition of unit 5. A radiocarbon sample from the top of unit 2 in the west wall yielded a calendar-corrected age of $2,730 \pm 100 \mathrm{cal}$ yr BP (table 1), which we interpret as a maximum-limiting age for PE3.

The best evidence of a fourth earthquake (PE4) is the presence of probable fault-scarp colluvium (unit 3) underlain by unit $2 \mathrm{~b}$ and overlain by units 4 or 5 in both trench walls south of faults FW5 and FE5. We did not observe any clear fault terminations at the base of unit 3 , but the lower boundary of a likely correlative deposit in the northern part of the trench 
(unit 3?) is marked by terminations of faults FW7, FW8, and FW10 from which we infer an earthquake horizon (PE4? EH) that we tentatively correlate with PE4 south of faults FE5 and FW5. The minimum age of earthquake PE4 is poorly constrained by the $2,730 \pm 100$ cal yr BP age from the top of unit 2 in the west wall.

\section{Paleoearthquake Timing}

Owing to our brief field time and a dearth of organic-rich sediments, we obtained only three samples of datable material from the Schist Creek Western trench (fig. 7, table 1). Thus, we lack complete maximum and minimum constraints for any of the four or five paleoearthquakes identified at Schist Creek, and thus can only make generalizations about the late Holocene history of the site.

Radiocarbon sample SCW-R01 consisted of a channel sample that extended from the surface to a depth of $36 \mathrm{~cm}$; it was intended to help constrain the age of the most recent earthquake, PE1. We selected carbonized fibers in a 1-cm-thick layer from a depth of about $14 \mathrm{~cm}$ from unit 7 that we hoped would provide a close-minimum age for PE1. Despite our efforts to avoid sampling fresh-appearing fibers, the sample yielded a modern age that may reflect post-1950 infiltration of "bomb" carbon and thus does little to constrain the time of this earthquake other than to suggest that it occurred within the past few hundred years.

We used sample SCW-R02 from the top of unit 5, directly beneath the PE2 earthquake horizon (fig. 7), to constrain the maximum age of PE2. This sample yielded a calibrated radiocarbon age of 1,210 $\pm 100 \mathrm{cal}$ yr BP and provides a maximum-limiting age for PE2. Unfortunately, we found no organic deposits suitable for radiocarbon dating above the earthquake horizon, so we have no close-minimum constraint on the age of PE2.

Paleoearthquake PE3 occurred after deposition of the glacial diamicton (unit 2) and before deposition of fluvial unit 5. Considering the geomorphic position of the Schist Creek site in the landscape, incision and filling of the fluvial channel may have been related to surface rupture during earthquake PE3. Earthquake-related displacement may have created a minor topographic depression along the toe of the scarp, which was then temporarily occupied by a small drainage flowing parallel to the scarp, perhaps during times of high runoff from snowmelt. A small drainage cut into the scarp about $50 \mathrm{~m}$ west (and uphill) of the trench is a likely source for this surface flow. Sample SCW-R03, from a peat stringer at the top of unit 2, yielded a calibrated radiocarbon age of 2,730 $\pm 100 \mathrm{cal}$ yr BP and thus provides a maximum-limiting age for PE3. Again, we found no organic deposits suitable for radiocarbon dating above the earthquake horizon, so we have no close-minimum constraint on the age of PE3. We found no datable materials associated with the PE4 or PE4? earthquake horizons; so the ages of these earthquakes are only poorly constrained as $>2,730 \pm 100 \mathrm{cal}$ yr BP and less than the age of glacial moraines in the region ( 17,000 cal yr; Matmon and others, 2006). If we assume that our record of recent surface ruptures at the Schist Creek site is complete, then our limited constraints indicate the following times of the past four ruptures: PE1, prehistoric (older than $\sim 1900$ A.D.), but very recent, possibly in the last $\sim 200-400$ years; PE2, older than $\sim 200-400 \mathrm{yr}$ and less than $\sim 1,200$ years ago; PE3, less than $\sim 2,700$ years ago; and PE4, more than $\sim 2,700$ years ago. Given the steep slope of the trenched scarp and evidence of erosion of the base of the scarp during initial channel incision (primarily south of horizontal trench meter 2 (fig. 7)) and subsequent deposition of unit 5, we suspect that our paleoseismic record at Schist Creek is incomplete.

\section{Discussion}

As noted by Schwartz and others (2014), fault scarps along the Denali fault system west of the 2002 rupture are geomorphically fresh and are clearly expressed in the landscape. The youthful expression of these scarps is first-order evidence that the youngest surface rupture on this part of the fault is only a few hundred years old. Our observations at Schist Creek corroborate the youthfulness of the youngest surface-rupturing earthquake (PE1), but we did not establish any firm constraints on the time of this rupture. On the basis of the geomorphic expression of the scarp, we estimate that the youngest surface rupture is on the order of 200-400 years old. This range is consistent with the inference of Schwartz and others (2005) that the youngest surface ruptures on this part of the Denali system occurred less than $(<) 250$ years ago.

Schwartz and others (2014) report that the penultimate surface rupture on the western part of the Denali fault system occurred between about 570 and 680 years before the 2002 rupture. Our data from Schist Creek indicate the penultimate earthquake (PE2) occurred some time after 1,200 cal yr BP, which is broadly consistent with the timing of the penultimate earthquake of Schwartz and others (2014). An alternative interpretation is that the PE2 at Schist Creek occurred very close to $1,200 \mathrm{cal}$ yr BP, and thus it does not correlate with the penultimate earthquake of Schwartz and others (2014). We have no close-minimum age constraints on PE2, so we cannot determine which of these alternative interpretations is more likely. We saw no evidence of erosion that might indicate an incomplete paleoseismic record since deposition of the cut-and-fill fluvial unit 5, but the subsequent deposits are thin $(<20-30 \mathrm{~cm})$ across the steeper part of the scarp near the most active fault traces (faults FW5, FW6, FE5), so it is possible that we missed evidence of an additional earthquake due to a lack of appreciable post-faulting deposition. 
Given our lack of closely constraining ages, we used the slip-rate data of Matmon and others (2006) to test whether our preliminary findings of three earthquakes since about 2,700 cal yr BP are reasonable. Matmon and others (2006) reported an average slip rate of $9.4 \pm 1.6 \mathrm{~mm} / \mathrm{yr}$ since $\sim 17 \mathrm{ka}$ at their nearby ("DFSC") slip-rate site (fig. $3 A$ ). As their site is only about $3 \mathrm{~km}$ west of our Western trench, it is likely that their slip rate represents the long-term rate at our site. If we apply a slip rate of $9.4 \pm 1.6 \mathrm{~mm} / \mathrm{yr}$ for the time interval between PE1 (200-400 yr) and the older possible age of PE2 ( 1,200 yr) at Schist Creek, then $6.25-11 \mathrm{~m}$ of strain should have accumulated in this $800-1,000 \mathrm{yr}$ interval. This amount of slip is substantial for a single earthquake along the Denali fault system; for comparison, Haeussler and others (2004) determined average slip of 4.5-5.1 $\mathrm{m}$ and a maximum slip of $8.8 \mathrm{~m}$ during the $2002 \mathrm{M} 7.9$ earthquake. So while we cannot rule out the occurrence of a single earthquake in the time period between our most recent earthquake (PE1) and PE2, our large values of accumulated strain indicate that the paleoseismic record at Schist Creek may be incomplete in the time period between 200 400 and 1,200 cal yr BP.

Likewise, application of the Matmon and others (2006) slip rate to the 1,500 yr time interval between our maximum ages for PE2 (1,200 yr) and PE3 (2,700 yr), yields an estimate of 11.7-16.5 m of strain accumulation between these two earthquakes. We find it unrealistic that this amount of strain would be released in a single surface-rupturing earthquake on this part of the Denali fault system, so we conclude that the paleoseismic record at Schist Creek probably is also incomplete in the time period between 1,200 and 2,700 cal yr BP.

Estimated recurrence intervals of 400-650 years between large earthquakes on the Denali fault system east of Denali (formerly Mt. McKinley) by Schwartz and others (2014) also suggest we may be missing one or more earthquakes in our paleoseismic history of the Schist Creek site. Possible explanations for these inferred gaps in our record include (1) erosion between deposition of units 2 and 7 destroyed the stratigraphic evidence of one or more earthquakes, or (2) the missing earthquakes ruptured an untrenched part of the fault zone. Our very limited trench and radiocarbon data prevent a conclusive assessment of earthquake activity at the Schist Creek site, but we infer that at least four and perhaps six or more large magnitude earthquakes ruptured the site in the last 2,700 cal yr BP (table 2).

Table 2. Inferred late Holocene paleoseismic history of the Schist Creek site.

[EQ, earthquake; PE, paleoearthquake]

\begin{tabular}{cccc}
\hline \hline $\begin{array}{c}\text { Inferred } 1 \\
\text { earthquake }\end{array}$ & $\begin{array}{c}\text { Western trench } \\
\text { earthquake }\end{array}$ & $\begin{array}{c}\text { Calibrated age } \\
\text { (cal yr bp) }\end{array}$ & Comments \\
\hline PEa & PE1 & $200-400^{*}$ & Age estimated from scarp morphology \\
PEb & -- & $>200-400^{*},<1,200 \pm$ & EQ inferred from long recurrence interval \\
& PE2 & $>200-400^{*}, \leq 1,200 \pm$ & ${ }^{14}$ C age may be close maximum \\
PEc & 100 & \\
PEd, PEe & -- & $>1,200,<2,700 \pm 100$ & EQs inferred from long recurrence interval \\
PEf & PE3 & $>1,200, \leq 2,700 \pm 100$ & ${ }^{14}$ C age may be close maximum \\
PEg & PE4 & $>2,700 \pm 100,<17,000$ & EQ predates PE3, deposition of unit 3 \\
PEg? & PE4? & $>2,700 \pm 100,<17,000$ & Probably PE4, if units 3 and 3? correlate \\
\hline
\end{tabular}

${ }^{1}$ Paleoearthquakes with evidence from Schist Creek Western trench in bold type.

${ }^{2}$ Estimated age marked with asterisk (*).

\section{Conclusions}

We excavated two trenches at the Schist Creek site, located about $44 \mathrm{~km}$ west of the western end of the 2002 rupture and $3 \mathrm{~km}$ east of the "DFSC" slip-rate site of Matmon and others (2006). We concentrated our effort on our Western trench because it contained clear evidence of several surface ruptures. On the basis of the combination of upward fault terminations and very limited radiocarbon dating, we identified clear evidence for four or five surface-rupturing earthquakes: the youngest surface rupture (PE1) probably occurred 200-400 years ago, the penultimate rupture (PE2) occurred $<1,200$ years ago, an 
older rupture (PE3) occurred $<2,700$ years ago, preceded by a fourth and possibly a fifth earthquake that predate 2,700 years ago. If we use our maximum age constraints as approximate times of PE2 and PE3, then interevent times between PE1 and PE2 and PE2 and PE3 are $\sim 800-1,000$ years and $\sim 1,500$ years, respectively. Such long intervals and the postglacial slip rate of $9.4 \pm 1.6 \mathrm{~mm} / \mathrm{yr}$ reported by Matmon and others (2006) yield unrealistic estimates of strain accumulation that point to probable gaps in the paleoseismic record of the Schist Creek site. Estimated recurrence intervals of 400-650 years on this part of the Denali fault system (Schwartz and others, 2014) also suggest an incomplete paleoseismic history at the site. Very steep scarp slopes, evidence of fluvial erosion along the trenched scarp, and a lack of field time to trench across the entire fault zone are likely causes of gaps in the earthquake history of the Schist Creek site. We use the results from our limited trench investigations, and the postglacial slip rate and estimated recurrence intervals from nearby parts of the fault zone, to infer four to six large magnitude earthquakes at Schist Creek in the last 2,700 cal yr BP (table 2).

\section{Acknowledgments}

The authors would like to thank Ahtna, Inc., for permission to conduct our investigation on tribal corporation property. We also thank Rob Witter and Peter Haeussler for excellent U.S. Geological Survey technical reviews, and MaryMargaret Coates for editorial review of the manuscript.

\section{References Cited}

Bemis, S.P., Weldon, R.J., and Carver, G.A., 2015, Slip partitioning along a continuously curved fault—Quaternary geologic controls on Denali fault system slip partitioning, growth of the Alaska Range, and the tectonics of south-central Alaska: Lithosphere, v. 7, no. 3, p. 235-246, doi:10.1130/L352.1.

Bronk Ramsey, Christopher, 2009, Bayesian analysis of radiocarbon dates: Radiocarbon, v. 51, no. 1, p. 337-360.

Carver, Gary, Plafker, G., Metz, M., Cluff, L., Slemmons, B., Johnson, E., Roddick, J., and Sorenson, S., 2004, Surface rupture on the Denali fault interpreted from tree damage during the 1912 Delta River $M_{w}$ 7.2-7.4 earthquakeImplications for the 2002 Denali fault earthquake slip distribution: Bulletin of the Seismological Society of America, v. 94, no. 6B, p. S58-S71.

Crone, A.J., Personius, S.F., Craw, P.A., Haeussler, P.J., and Staft, L.A., 2004, The Susitna Glacier thrust faultCharacteristics of surface ruptures on the fault that initiated the 2002 Denali fault earthquake: Bulletin of the Seismological Society of America, v. 94, no 6B, p. S5-S22.

EarthScope Alaska Denali Totschunda Lidar Project, 2008, doi:10.5069/G9QN64NF, available at: http://opentopo.sdsc.edu/gridsphere/gridsphere?gs_action=datasetMetadata\&cid=geonlidarframeportlet\&otCollectionID= OT.102009.32607.1.

Eberhart-Phillips, Donna, and 28 others, 2003, The Denali fault earthquake, Alaska-A large magnitude, slip-partitioned event: Science, v. 300, no. 5622, p. 1113-1118, doi: 10.1126/science.1082703.

Elliott, J.L., Larsen, C.F., Freymueller, J.T., and Motyka, R.J., 2010, Tectonic block motion and glacial isostatic adjustment in southeast Alaska and adjacent Canada constrained by GPS measurements: Journal of Geophysical Research, v. 115, Issue B09, B09407, doi:10.1029/2009JB007139.

Fuis, G.S., and Wald, L.A., 2003, Rupture in south-central Alaska-The Denali fault earthquake of 2002: U.S. Geological Survey Fact Sheet 014-03, 4 p., available at: http://pubs.usgs.gov/fs/2003/fs014-03/index.html).

Haeussler, P.J., 2008, An overview of the neotectonics of interior Alaska-Far-field deformation from the Yakutat microplate collision, in Freymueller, J.T., Haeussler, P.J., Wesson, R., and Ekstrom, G., eds., Active tectonics and seismic potential of Alaska: American Geophysical Union Geophysical Monograph 179, Washington, D.C., p. 83-108.

Haeussler, P.J., 2009, Surface rupture map of the 2002 M7.9 Denali fault earthquake, Alaska—Digital data: U.S. Geological Survey Digital Data Series 422, v. 1.0, available at: http://pubs.usgs.gov/ds/422/.

Haeussler, P.J., Matmon, A., Schwartz, D.P., Seitz, G., and Crone, A.J., 2012, The Denali fault and interior Alaska tectonics in mid- to late-Cenozoic time [abs.]: Washington, D.C., American Geophysical Union Fall meeting, abstract T14A-04.

Haeussler, P.J., Schwartz, D.P., Dawson, T.E., Stenner, H.D., Lienkaemper, J.J., Sherrod, Brian, Cinti, F.R., Montone, P., Craw, P.A., Crone, A.J., and Personius, S.F., 2004, Surface rupture and slip distribution of the Denali and Totschunda faults in the 3 November 2002 M 7.9 earthquake, Alaska: Bulletin of the Seismological Society of America, v. 94, no. 6B, p. S23-S52.

Hall, W.J., Nyman, D.J., Johnson, E.R., and Norton, J.D., 2003, Performance of the Trans-Alaska Pipeline in the November 3, 2002, Denali fault earthquake, in Beavers, J.E., ed., Advancing Mitigation Technologies and Disaster Response for Lifeline Systems: U.S. Conference and Workshop on Lifeline Earthquake Engineering, Sixth, TCLEE 2003, Proceedings, American Society of Civil Engineers, p. 522-534. doi: 10.1061/40687(2003)54. 
Honegger, D.G., Nyman, D.J., Johnson, E.R., Cluff, L.S., and Sorensen, S.P., 2004, Trans-Alaska pipeline system performance in the 2002 Denali fault, Alaska, earthquake: Earthquake Spectra, v. 20, no. 3, p. 707-738.

Jibson, R.W., Harp, E.L., Schulz, W., and Keefer, D.K., 2004, Landslides triggered by the 2002 Denali fault, Alaska, earthquake and the inferred nature of the strong shaking: Earthquake Spectra, v. 20, no. 3, p. 669-691.

Koehler, R.D., 2013, Quaternary faults and folds (QFF): Alaska Division of Geological and Geophysical Surveys Digital Data Series 3, available at: http://maps.dggs.alaska.gov/qff/.

Koehler, R.D., Farrell, R.-E., Burns, P.A.C., and Combellick, R.A., 2012, Quaternary faults and folds of Alaska-A digital database: Alaska Division of Geological and Geophysical Surveys Miscellaneous Publication MP-141, 31 p., 1 oversize sheet.

Matmon, Ari, Schwartz, D.P., Haeussler, P.J., Finkel, R., Lienkaemper, J.J., Stenner, H.D., and Dawson, T.E., 2006, Denali fault slip rates and Holocene-late Pleistocene kinematics of central Alaska: Geology, v. 34, no. 8, p. 645-648, doi: 10.1130/G22361.1.

Mériaux, A.-S., Sieh, K., Finkel, R.C., Rubin, C.M., Taylor, M.H., Meltzner, A.J., and Ryerson, F.J., 2009, Kinematic behavior of southern Alaska constrained by westward decreasing postglacial slip rates on the Denali fault, Alaska: Journal of Geophysical Research, v. 114, p. B03404, doi:10.1029/2007JB005053.

Plafker, George, Gilpin, L.N., and Lahr, J.C., 1994, Neotectonic map of Alaska, in The geology of Alaska: Plafker, George, and Bell, H.C., eds., Geological Society of America, Boulder, Colorado, v. G-1 of the Geology of North America, plate 12 , scale $1: 2,500,000$.

Reed, B.L., and Lanphere, M.A., 1974, Offset plutons and history of movement along the McKinley segment of the Denali fault system, Alaska: Geological Society of America Bulletin, v. 85, p. 1883-1892.

Reimer, Paula, Bard, E., Bayliss, A., Beck, J., Blackwell, P., Bronk Ramsey, C., Buck, C., Cheng, H., Edwards, R., Friedrich, M., Grootes, P., Guilderson, T., Haflidason, H., Hajdas, I., Hatté, C., Heaton, T., Hoffmann, D., Hogg, A., Hughen, K., Kaiser, K., Kromer, B., Manning, S., Niu, M., Reimer, R., Richards, D., Scott, E., Southon, J., Staff, R., Turney, C., and Van Der Plicht, J., 2013, IntCal13 and Marine13 radiocarbon age calibration curves 0-50,000 years cal BP: Radiocarbon, v. 55, no. 4, p. 1869-1887.

Riehle, J.R., Fleming, M.D., Molnia, B.F., Dover, J.H., Kelley, J.S., Miller, M.L., Nokleberg, W.J., Plafker, George, and Till, A.B., 1997, Digital-shaded relief image of Alaska: U.S. Geological Survey, Geologic Investigations Series I-2585, scale $1: 2,500,000$.

Schwartz, D.P., Haeussler, P.J., Seitz, G.G., Dawson, T.E., Stenner, H.D., Matmon, A., Crone A.J., Personius, S.F., Burns, P.B., Cadena, A., and Thoms, E., 2005, Unraveling the earthquake history of the Denali fault system, Alaska-Filling a blank canvas with paleoearthquakes [abs.]: Eos Transactions, American Geophysical Union, v. 86, no. 52, Fall Meeting Supplement, abstract U42A-06.

Schwartz, D.P., Haeussler, P.J., Seitz, G.G., Koehler, R.D., Personius, S.F., Crone, A.J., and Dawson, T.E., 2014, Recurrence of large earthquakes along the Denali fault system [abs]: Seismological Society of America Annual Meeting, Seismological Research Letters, v. 85, no. 2, p. 474.

Seitz, G.G., Haeussler, P.J., Crone, A.J., Lipovsky, Panya, and Schwartz, D.P., 2008, Eastern Denali fault slip rate and paleoseismic history, Kluane Lake area, Yukon Territory, Canada [abs.]: Eos Transactions American Geophysical Union, v. 89, no. 53, Fall Meeting Supplement, abstract T53B-1947.

Sherwood, K.W., and Craddock, Campbell, 1979, General geology of the central Alaska Range between the Nenana River and Mount Deborah: Alaska Division of Geological and Geophysical Surveys Open File Report 116, 22 p., 3 plates, scale $1: 63,360$.

St. Amand, Pierre, 1957, Geological and geophysical synthesis of the tectonics of portions of British Columbia, the Yukon Territory, and Alaska: Geological Society of America Bulletin, v. 68, no. 10, p. 1343-1370, doi:10.1130/0016-7606 (1957)68[1343:GAGSOT]2.0.CO;2.

U.S. Geological Survey and Alaska Department of Natural Resources, 2006, Quaternary fault and fold database for the United States, accessed January 16, 2014, from U.S. Geological Survey web site: http//earthquake.usgs.gov/hazards/qfaults. 


\section{\#USGS}
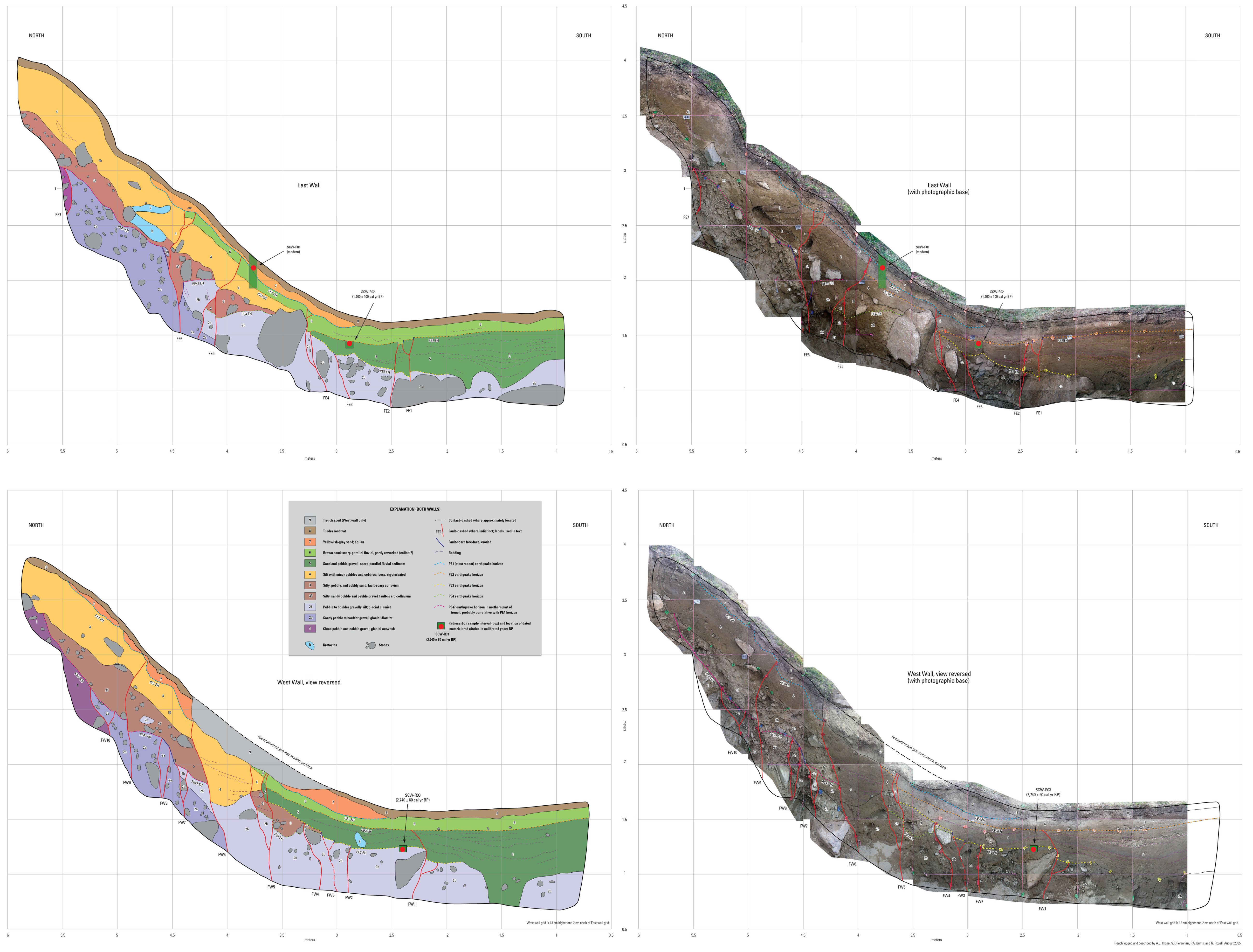

Figure 7. Logs and photomosaics of stratigraphy and faults exposed in the east and west walls of the Western trench at the Schist Creek site. Faults in the east wall are numbered with the prefix "FE" and those in the west wall are numbered with the preffix "FW." See text for discussion of stratigraphy and faulting history. 